\title{
SHAHJALAL FERTILIZER COMPANY LIMITED (SFCL): IN RETROSPECT
}

\author{
A.K.M.A. Quader * \\ Professor of Chemical Engineering (Retired), BUET, Dhaka and Consultant to BCIC/SFP
}

\begin{abstract}
This is a reflection on the implementation of Shahjalal Fertilizer Project (SFP) what is today Shahjalal Fertilizer Co. Ltd. (SFCL). This deals with a wide range of issues covering technical, contractual, and administrative involving SFP, General Contractor, sub-contractors, Process Licensors and vendors. These arose because of mindset, interpretation of contract clauses, inexperience, expectation and frustration of both Owner and General Contractor. Lessons learned would enable BCIC to undertake such projects in future by avoiding pitfalls and missteps of SFP.
\end{abstract}

Keywords: SFCL, BCIC, COMPLANT, CHENGDA, KBR, Stamicarbon, Ammonia, Urea

\section{Introduction}

Shahjalal Fertilizer Company Ltd. (SFCL) is the new ammonia-urea grass-roots fertilizer complex under Bangladesh Chemical Industries Corporation (BCIC), a public sector corporation under the Ministry of Industries. The complex produces granular urea along with the intermediate product ammonia using natural gas as feedstock and fuel. It is the eighth ammonia-urea complex in Bangladesh and the seventh under BCIC. It is located at Fenchugonj, Sylhet beside the first ammonia-urea complex NGFF (Natural Gas Fertilizer Factory) commissioned in December 1960. NGFF has been closed permanently since the start-up of SFCL. It is yet to be decommissioned.

The design capacities of SFCL at $100 \%$ load for 330 stream days are:

$$
\begin{array}{ll}
\text { Ammonia } & 1000 \text { tpd (330,000 tpy) } \\
\text { Granular Urea } & 1760 \text { tpd (580,800 tpy) }
\end{array}
$$

SFCL has been built on a Lump Sum Turn Key (LSTK) basis and the General Contractor (GC) is China National Complete Plant Import and Export Corporation Limited (COMPLANT) selected by the Government of China.

During its implementation stage, SFCL was known as Shahjalal Fertilizer Project (SFP). It was scheduled to be completed in 38 months per the contract. Though the contract was signed on December 11, 2011, the effective date of contract (EDC) was April 16, 2012 for completing all - formalities required to make the signed contract legally effective. The contracted completion date for the project thus became June 15, 2015.

\section{Background of SFL}

BCIC has been planning to build two ammoniaurea fertilizer complexes since the commissioning of Jamuna Fertilizer Co. Ltd. (JFCL), one in Sylhet area if possible beside NGFF and another in the northwestern region on the western bank of the river Jamuna. The purpose of the two new fertilizer complexes was to meet the growing demand of urea fertilizer in the country to achieve food autarky as well as to replace NGFF commissioned in 1960. NGFF, when planned and built, was based on the state of the art process technologies for ammonia and urea. However, advances made since in process technologies and equipment have made it less energy efficient. Even in 2009-10 NGFF produced 55,400 t urea with natural gas consumption of $67 \mathrm{MSCF}$ per ton of urea against the design rate of $59 \mathrm{MSCF}$.

The Government of Bangladesh through a notification (Order/Misc. 26/93/43 dated 2.12.1993) constituted a committee to assess the possibility of continuing safe operation of NGFF beyond December 1993, the deadline fixed by the Government to close down NGFF. The committee recommended, 'NGFF can be safely operated beyond 1993 with the provision that increased vigilance be maintained over and above routine maintenance. 
The suggested overhauling should be able to keep NGFF operational for about three or more years during which the proposed Shahjalal Fertilizer Factory will come to fruition.' BCIC failed to provide funds for the recommended overhauling. Nevertheless, NGFF, with on and off maintenance and repairs, remained in operation until the power plant failed to supply power due to damage of the main transformers in June 2014.

During the period 1993 through 2000 the factory used spares worth Tk. 65.14 million (Tk. 9.30 million per annum). When the decision was taken to close down NGFF by December 31, 1993, the factory during the preceding seven years (1986 - 1993), had produced annually $100,135 \mathrm{t}$ urea on an average against the rated annual capacity of $106,000 \mathrm{t}$. After December 31, 1993 when NGFF was allowed to operate, it produced $87,164 \mathrm{t}$ urea per year on average during the period from 1993 to 2000. During the period from 2001 to 2010 the factory produced $76,780 \mathrm{t}$ urea per annum on average and the production started to decline from $63,010 \mathrm{t}$ in 2007 08 to $55,426 \mathrm{t}$ in $2009-10$. Table 1 is a summary of the production of NGFF from 1986 to 2010.

Table 1

Summary of the production of NGFF from 1986 to 2010

\begin{tabular}{lcc}
\hline Period & $\begin{array}{c}\text { Average Annual } \\
\text { Production of Urea, tons }\end{array}$ & $\begin{array}{c}\text { Capacity } \\
\text { Utilization, \% }\end{array}$ \\
\hline $\begin{array}{l}1986-87- \\
1992-93\end{array}$ & 100,135 & 94.5 \\
$1993-94-$ & 87,164 & 82.2 \\
$1999-00$ & & \\
$2000-01-$ & 76,780 & 72.4 \\
$2001-10$ & & \\
$2007-08$ & 63,010 & 59.4 \\
$2009-10$ & 55,426 & 52.3 \\
\hline
\end{tabular}

BCIC and the Ministry of Industries treated NGFF harshly by calling it a losing plant and gas hungry monster. NGFF was losing because it was forced to sell urea at a price (below the cost of production) fixed arbitrarily by the Government ignoring the urea price in the world market from where BCIC had been buying urea at cost of US $\$ 350-800$ per ton, Figure 1. The plant has been operating with gas consumption close to design value. With the rationing of gas and suspension gas supply matters worsened for all the BCIC urea plants. BCIC now is more interested in importing urea instead of producing it in its plants, Figure 2.

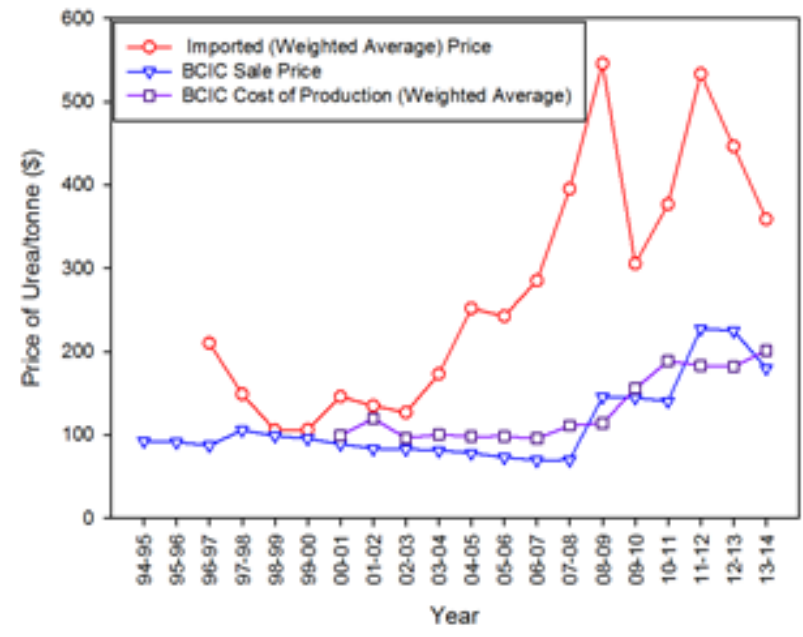

Figure 1. Import Price, BCIC's Sale Price and BCIC's Production Costs of UREA [1].

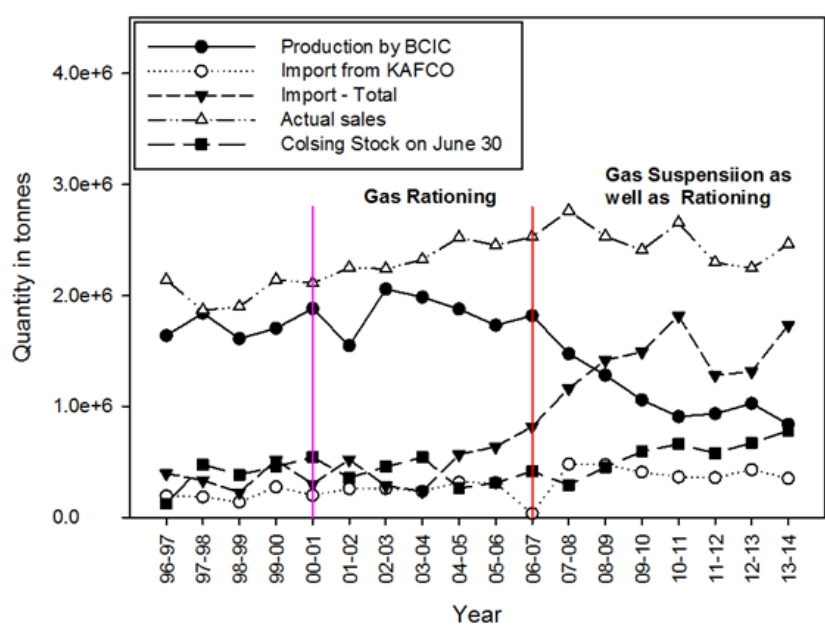

Figure 2. Urea Sale, BCIC's Production, Import of Urea and Year End Stock [1]

\section{Funding Arrangement}

SFCL was financed through a mixed loan comprising of the Chinese Government Concessional Loan (CGCL) and Preferential Buyer's Credit (PBC) from the Exim Bank of China. The Chinese Government provided RMBY (Reni Min Bi Yuan) 1.6 billion (US \$ 234 million) and Exim Bank provided US \$ 325 million. The terms and conditions are:

Interest rate: $2 \%$ per annum

Management fee: $0.2 \%$ at a time

Commitment fee: $0.2 \%$ (payable at interval of 180 days on undisbursed loan amount)

Maturity Period: 20 years including 5 years grace period 
The funds provided by China did not cover the LSTK contract price and the Government of Bangladesh provided Tk. 1,514.25 million (US \$ 20.19 million). One of the conditions for utilizing Chinese funds was that a sizeable quantity of goods and services would be procured from China.

\section{Appointment of General Contractor}

As a condition for availing loan from the Chinese Government for a project, the Government of China appointed a Chinese General Contractor following its own procedure. COMPLANT was the appointed General Contractor. No document was presented to GoB from the Chinese Government about qualification, experience and competence of COMPLANT to undertake a grass-roots ammoniaurea complex of comparable size of SFP.

When COMPLANT had submitted its proposal (technical and commercial) in September 2010, it was found that COMPLANT had not acted as a GC for any ammonia-urea grass-roots project in the past. It involved China Chengda Engineering Co. Ltd (CHENGDA) as sub-contractor for providing technical support to complete the project. A MoU was signed between COMPLANT and CHENGDA on October 28, 2010 outlining roles, responsibilities and job distribution for implementing SFP.

A similar situation arose while implementing Ashugonj Fertilizer Complex Ltd. (AFCL) at the insistence of the World Bank. The appointed GC Foster Wheeler (UK) was disqualified at the prequalification stage; but it was thrust upon Bangladesh by WB when Foster Wheeler submitted a bid by associating Uhde Engineering, Germany as its subcontractor for technical support. Though Uhde Engineering was prequalified as GC for AFCL, it declined to participate in bidding. There is a difference here between CHENGDA and Uhde considering their expertise and capabilities. Uhde was the process licensor for ammonia process and process licensee of Stamicarbon's urea process. In contrast, CHENGDA was neither process licensor nor licensee of any process technology involved but it had worked with process licensors in a number of projects in the past. CHENGDA had no experience with Stamicarbon's Urea Granulation process as well as with Pool Reactor.

\section{Proposal by COMPLANT}

COMPLANT submitted its preliminary proposal (technical and contract) to BCIC for its consideration on September 27, 2010. The proposal did not provide any evidence of COMPLANT's actual experience as GC for planning, design and construction of a grassroots ammonia-urea complex having the capacity of SFP by engaging CHENGDA for engineering, design and management services using processes of KBR (Ammonia), Stamicarbon (Urea Melt) and Ho Fung (Urea Granulation).

It provided 'Design Basis' of Tarakandi where JFCL is located instead of Fenchugonj where SFP would be built. Ho Fung did not have experience outside China and the process itself had incorporated concepts of other processes without permission. This implies that there would be legal problems if this technology is used in Bangladesh. COMPLANT did not mention the version of processes for ammonia and urea melt to be used in SFP. Diagrams and documents such as PFD, P\&ID, process descriptions, material and energy balances, plot plan, guarantee figures etc. had not been reviewed by process licensors.

When COMPLANT was told about various inconsistencies and incompleteness, it revised its technical proposals several times. Following the discussion between BCIC and COMPLAMT during the period October 18, 2010 to December 13, 2010 process technologies, scope of works and supplies, plant configuration etc were settled. Processes selected were:

\section{Ammonia: KBR Purifier TM Process \\ Carbon Dioxide Removal: BASF aMDEA Process \\ Urea Melt: Stamicarbon Urea 2000 plus (Pool Reactor Process) \\ Urea Granulation: Stamicarbon Fluid Bed Granulation Process}

The process air compressor of the ammonia plant would be Gas Turbine driven.

\section{Meeting with Process Licensors before Evaluation of GC's Proposal}

COMPLANT, at the request of BCIC, invited the process licensors KBR and Stamicarbon to Dhaka for a meeting with BCIC seeking clarification of a wide range of issues. BCIC prepared a set of questionnaires for the meeting with licensors. KBR and BCIC met on December 06 and 07, 2010 and responses from KBR for each point and question were recorded. A minute of this meeting was signed by KBR and BCIC. Similarly, Stamicarbon and BCIC met on December 08 and 09, 2010 and responses from Stamicarbon for each point and question were recorded. A minute of the meeting was signed between Stamicarbon and BCIC. 
Both KBR and Stamicarbon mentioned that COMPLANT had no direct relationship with them but they had licensed their processes through CHENGDA on a project-by-project basis and they would deal with CHENGDA in the same way for SFP. CHENGDA was yet to execute any Stamicarbon Pool Reactor plant and Granulation unit. As CHENGDA had experience of building Stamicarbon's Pool Condenser plant, Stamicarbon has full confidence in CHENGDA's ability and competence for engineering and construction of its Pool Reactor plant using its engineering package. Both licensors disclosed the contents of the engineering package for each process and what they would undertake as a part of basic engineering, detailed engineering and review of detailed engineering to be completed by CHENGDA, review of vendors' drawings and documents as listed in licensing agreement. They also revealed that they were yet to go through the technical proposals submitted to BCIC by COMPLANT. They could do it if BCIC would sign a Secrecy Agreement to hold all information supplied confidential. KBR sent to BCIC a format of the Secrecy Agreement and BCIC took more than three months to sign and send the Secrecy Agreements to licensors because of misconceived perception about the Secrecy Agreement.

\section{Contract Price}

The LSTK contract price agreed was US \$ 580.19 million (Tk. 43,514.25 million) as follows:

a. Chinese Government Concessional Loan: US $\$ 235$ million (Chinese Yuan 1.6 billion)

b. Exim Bank of China (Preferential Buyer's Credit): US \$ 325 million

c. Govt. of Bangladesh: US \$ 20.19 (Tk. 1,514.25 million)

The local currency portion of Tk. 1,514.25 million of the LSTK price reflected transferring certain works from SFP's scope to GC's scope. These works included: Construction of Administration Building, Housing Colony, Medical Center, Mosque, Local Training by GC, etc. If SFP builds Housing Colony COMPLANT cannot claim it. BCIC and COMPLANT initialed the Draft Contract on the agreed LSTK price of US \$ 580.19 million on September 28, 2011. When COMPLANT submitted its proposal, the LSTK price quoted was US \$ 665 million. The total project cost estimated by BCIC was Tk 54,090 million (US 721 million) consisting of agreed LSTK price and other related costs that include Working Capital, Price Escalation and Contingency, Revenue Component, CD-VAT etc.
Physical and Price Contingency plus CD-VAT accounted for Tk. 9,899 million (US\$ 132 million). A breakdown of LSTK price under a broad heading is shown in Table 2.

Table 2

Breakdown of LSTK price

\begin{tabular}{|c|c|c|c|c|}
\hline & Breakdown of Items & US \$ & RMB Y & Tk. \\
\hline $\mathrm{a}$ & $\begin{array}{l}\text { Site investigation and } \\
\text { Survey }\end{array}$ & 0.060 & & \\
\hline b & $\begin{array}{l}\text { Land Development for } \\
\text { Plant Site }\end{array}$ & 1.800 & & \\
\hline c & Ammonia Unit & 159.623 & 186.084 & 75.000 \\
\hline d & $\begin{array}{l}\text { Urea Unit (Melt and } \\
\text { Granulation) }\end{array}$ & 83.549 & 93.125 & \\
\hline $\mathrm{e}$ & $\begin{array}{l}\text { Product Storage and } \\
\text { Package }\end{array}$ & 4.847 & 156.094 & \\
\hline $\mathrm{f}$ & Utilities and Offsites & 14.295 & 955.120 & 69.000 \\
\hline $\mathrm{g}$ & $\begin{array}{l}\text { Construction } \\
\text { Equipment }\end{array}$ & 4.188 & & \\
\hline $\mathrm{h}$ & Freight and Insurance & 7.285 & & 267.000 \\
\hline $\mathrm{i}$ & Temporary Facilities & 0.878 & & \\
\hline $\mathrm{j}$ & Office Services & 4.993 & 46.080 & \\
\hline $\mathrm{k}$ & $\begin{array}{l}\text { Process Licensing and } \\
\text { Technical Services }\end{array}$ & 33.271 & 123.500 & \\
\hline 1 & Vendors' Services & 2.220 & & \\
\hline $\mathrm{m}$ & $\begin{array}{l}\text { Training (Foreign and } \\
\text { Local) }\end{array}$ & 1.038 & 9.227 & 267.000 \\
\hline $\mathrm{n}$ & Vehicles for SFP & 0.880 & & 69.000 \\
\hline $\mathrm{o}$ & $\begin{array}{l}\text { Performance Test Runs } \\
\text { and Start-up }\end{array}$ & 2.600 & 12.932 & \\
\hline $\mathrm{p}$ & $\begin{array}{l}\text { Spare Parts for 2-years } \\
\text { Operation }\end{array}$ & 3.473 & 23.838 & \\
\hline $\mathrm{q}$ & $\begin{array}{l}\text { Construction of } \\
\text { Housing Facilities for } \\
\text { SFP }\end{array}$ & & & $767.258^{*}$ \\
\hline & TOTAL & 325.000 & 1600.000 & 1514.250 \\
\hline
\end{tabular}

\section{Signing of the Contract}

The Contract between BCIC and COMPLANT was signed on December 11, 2011 with project completion period of 38 months from the Effective Date of the Contract (EDC) to the issue date of the Final Acceptance Certificate while the draft contract was initialed on September 28, 2011. It took more than four months to complete all formalities for the contract to be legally effective. The effective date was April 16, 2012 and the project completion date thus became June 15, 2015. 


\section{Configuration of the Project}

The configuration of SFP is as follows:

a. Ammonia Unit: 1000 tpd (It shall produce sufficient carbon dioxide for urea production)

b. Urea Melt Unit: 1760 tpd

c. Urea Granulation Unit: 1760 tpd

d. Ammonia (liquid) Product Storage Tank: 10,000 t at atmospheric pressure and $-33^{\circ} \mathrm{C}$

e. Bulk Urea Storage: $70,000 \mathrm{t}$

f. Bagged Urea Storage: $15,000 \mathrm{t}$

g. Boiler (natural gas fired): $75 \mathrm{t} / \mathrm{hr}, 2$ units, steam pressure and temperature: $5 \mathrm{MPG}, 400^{\circ} \mathrm{C}$

h. Steam Turbine \& Generator (STG): Turbine, 2 Units, MP steam 4.6 MPG and $400 \mathrm{C}$ Generator, 2 Units, Output $12 \mathrm{MW}$ each, $6.3 \mathrm{kV}, 3$ phase, 50 $\mathrm{Hz}$ and pf 0.80

i. Water Intake: $1000 \mathrm{~m}^{3} / \mathrm{hr}$

j. Water Treatment Plant: Input $1000 \mathrm{~m}^{3} / \mathrm{hr}$, Project requirement

k. Cooling Water System

1. Ammonia Unit, Power Plant and Air Compressor: $15,330 \mathrm{~m}^{3} / \mathrm{hr}$ (5 cells)

2. Urea Unit: $9,200 \mathrm{~m}^{3} / \mathrm{hr}$ (3 cells)

1. Demineralization Unit

1. Demineralized Water: $120 \mathrm{~m}^{3} / \mathrm{hr}$

2. Polished Water: $167 \mathrm{~m}^{3} / \mathrm{hr}$

m. Instrument and Plant Air System: $3500 \mathrm{~m}^{3} / \mathrm{hr}$

n. Inert Gas Generation Unit: $450 \mathrm{Nm}^{3} / \mathrm{hr}$ of Nitrogen

o. Urea Handling

1. Reclaiming to Bagging Plant: $300 \mathrm{t} / \mathrm{hr}$

2. Bagging Capacity: $240 \mathrm{t} / \mathrm{hr}$

3. Bagged Urea Truck Loading Capacity: $300 \mathrm{t} / \mathrm{hr}$

4. Facility for Train Loading: 2 Loading Machine

p. Emergency Diesel Generator: $1 \mathrm{MW}, 400 \mathrm{~V}$

q. Emergency Diesel Generator (Black Start): 1.8 MW, $6.3 \mathrm{kV}$

r. UPS: To meet the need of DCS and all instruments for 30 minutes when power fails

s. Stand-by Power from PDB: $10 \mathrm{MW}, 132 \mathrm{kV}$

t. Polythene Bag Making Plant (liner): 36,400 bags per $24 \mathrm{hrs}$

u. Ammonia Bottling Plant: $50 \mathrm{~kg}$ bottles, 200 bottled/day

v. Natural Gas Metering Station inside the Plant B.L.

w. Jetty on the Bank of the Kushiara River: 300-500 tonnage transfer barge berthing

x. Major Buildings: Central Control Room, Technical, Laboratory, Workshops for mechanical, electrical and instrument, stores for spare parts, chemicals, insulation etc, Fire Fighting, Control Rooms for Utilities and Offsite as required

y. All roads, drains, fence, slope protection and boundary walls within the Project B.L
The plant layout has kept aside sufficient space for installing facilities for the production of urea super granules at the rate of $300 \mathrm{t} /$ day at the request of the Ministry of Agriculture.

\section{Work Schedule}

The project milestones with reference to the Effective Date of the Contract (EDC) are listed in Table 3.

Table 3

Project milestones

\begin{tabular}{ll}
\hline Milestone & Month from EDC \\
\hline Effective Date of Contract & 0 \\
Handover of the Land to GC & 1 \\
Kick-off Meeting & 1 \\
Land Development Start & 2 \\
Basic Engineering Design (BED)Start & 2 \\
Long Lead Equipment Inquiry & $4-5$ \\
Basic Engineering Design Review Meeting & $7-8$ \\
Land Development Finish & 9 \\
Piling Start & 10 \\
1st Lot Delivery at the Site & 12 \\
Civil Works Start & 12 \\
3-D model Review & 15 \\
Detailed Engineering Design Finish & 19 \\
Water Intake and Water Treatment Plant in & 24 \\
Operation & 38 \\
Natural Gas Metering Station put into Operation & 26 \\
Demi-water Unit put into Operation & 27 \\
Power Plant Boilers (Auxiliary Boilers) put into & 28 \\
Operation & 34 \\
Power Plant in Operation & \\
Mechanical Completion & 29 \\
Pre-commissioning and Commissioning Start & 34 \\
Performance Test Runs & 28 \\
Final Plant Acceptance & 28 \\
\hline & \\
\hline
\end{tabular}

\section{Handover of the Land to GC by SFP}

Once the site for the project had been selected beside NGFF Complex, COMPLANT submitted the Overall Plot Plan. Accordingly, SFP started to handover the site to COMPLANT and it could not handover the entire land within one month from the effective date of the contract. The last piece of the land (measuring $300 \mathrm{~m}$ by $80 \mathrm{~m}$ ) where cooling towers and ammonia storage tanks are located was handed over in March 2013 after dismantling existing housing colonies and structures. 
As per the contract COMPLANT would be entitled to an extension of project completion time if the land could not be handed over within 45 days from EDC. COMPLANT throughout the project implementation raised this issue of delay for the land handover in every monthly progress report and asked for an extension of the project completion date. However, SFP refused to take it into cognizance. This delay was due to inability of BCIC and the Ministry of Industries to decide the fate of NGFF and its employees when the implementation of SFP had begun. In March 2015, it was decided to close down NGFF and absorb its personnel in SFP as appropriate.

\section{Kick-off Meeting (KOM)}

COMPLANT submitted its working paper for the KOM, which was to be held in Dhaka with the participation of SFP, BCIC, COMPLANT, CHENGADA and Process Licensors KBR and Stamicarbon in April 2012 before the contract became effective. The KOM began on April 17, 2012 while the contract became effective on April 16, 2012. COMPLANT failed to get the Process Licensors to the meeting. Issues to be covered in the KOM proposed by COMPLANT included:

Review of Overall Plot Plan

Schedule of Land Handover

Tie-in points of B.L. for gas, electricity, water and others based on the Plot Plan

Description and Sizing of Utilities and Offsite

Design Basis for Civil Engineering

Project Schedule

Progress Approval Procedure

Project Coordination Procedure

Organization and responsibilities of the parties involved in the project

However, the KOM was held covering these:

Project Scope

Goals and Deliverables

Project Site

Project Assumptions

Project Organization

Key Success Factors

Project Reporting and Document Control

Quality Assurance and Quality Control

Environment, Health and Safety (HSE)

Overall Plot Plan

SFP and COMPLANT agreed to hold discussions in parallel by forming five groups covering following areas:
Group-A: Plot Plan and Civil Construction

Group-B: Ammonia, Urea Melt and Urea Granulation

Group-C: Utilities and Offsite

Group-D: Project Management

Group-E: Project Management and Coordination

Meetings were held on April 16-19 and 25-26, 2012. It was CHENGDA who provided resource personnel for each of these groups and completed discussions, while COMPLANT's input was limited. Absence of Process Licensors left many grey areas regarding the relationship and involvement of Process Licensors with SFP/BCIC. The Licensors failed SFP/BCIC during the execution phase by not responding to SFP/BCIC's queries and clarifications contrary to what they had agreed in the meetings with them in December 2010 during the evaluation of COMPLANT's proposal.

The overall plot plan was reviewed and approved for planning purpose. However, COMPLANT asked for additional space on the north-eastern side and it was agreed to extend the length towards the northsouth direction by about 80 meters. While discussing the construction type of ammonia storage tank COMPLANT explained that its proposal was based on 10,000 t tank of single wall type construction. Construction type could not be resolved as SFP had insisted on a Double Wall-type construction. COMPLANT agreed to obtain quotations for spare rotors for major compressors and turbines while placing orders with the vendors to facilitate BCIC to purchase these as optional items.

COMPLANT agreed to submit Licensing Agreements to SFP as early as possible, but it did not hand over the copies of these agreements for months even after the signing of the agreements that did not stipulate BCIC's relationships with Licensors. This was a breach of understanding reached by BCIC with individual process licensor and CHENGDA in December 2010. This shall be a lesson for the future projects in Bangladesh. If the OWNER is to have a relationship with the licensors, it shall be a party to the licensing agreements by stipulating the obligations of the Licensors to Owner.

\section{Basic Engineering Design (BED) Review Meeting}

A Basic Engineering Design (BED) Review Meeting took place at the Home Office of CHENGDA in Chengdu, China from November 05 to 16,2012 . As part of preparation for BED review meeting COMPLANT submitted to SFP a number of Engineering Specifications, Plot Plan, BED of Offsite 
and Utilities plus Process Design Package of Process Licensors (compiled by CHENGDA as its BED for ammonia, urea melt and urea granulation plants) just few days before the departure of SFP's team for Chengdu. The SFP team did not have time to go through these documents in Dhaka. Personnel from KBR and Stamicarbon participated in BED review meeting. Stamicarbon informed that it had not reviewed the BED documents submitted by CHENGDA and it would review these upon returning to the Netherlands. Stamicarbon asked CHENGDA to incorporate its comments in the BED documents prepared by CHENGDA and thereafter, CHENGDA would submit these documents to SFP. But CHENGDA did not submit these reviewed documents to SFP duly.

Stamicarbon pointed out that CHENGDA had no previous experience of engineering Stamicarbon's Urea Pool Reactor and also Urea Granulation Process. As a result, Stamicarbon itself would complete detailed engineering of Urea Pool Reactor and Urea Granulation Unit including necessary procurement of proprietary equipment and materials.

KBR during the meeting submitted its recommendations of design margin for its ammonia process and plant equipment. KBR also informed that equipment design would have built-in margin following API or KBR design standards. For noncritical equipment COMPLANT would use Chinese standards as mentioned in the contract.

It was agreed that the ammonia storage tank capacity would be $10,000 \mathrm{t}$ and decision remained pending whether the tank would be single wall or double wall. It would be decided in Dhaka before December 15, 2012.

BEDs for utilities, offsites and buildings were reviewed. Necessary feedbacks from SFP were provided to the engineers of CHENGDA as it became evident that the engineers of CHENGDA had failed to fully understand and appreciate the basis for the design of different utilities and offsites with respect to capacity, duty, margins and strategy for operation. These engineers were not in Dhaka during the negotiation and SFP's requirements were not correctly placed to them.

CHENGDA provided a list of Chinese codes and standards to be used in the project for equipment, machinery and materials to be procured from China. It did not provide these codes and standards to SFP immediately.

The overall plot plan submitted for review had already been extended on the east side. The plot plan looked satisfactory from the viewpoint of B.L.s of process plants, control room, utilities, ammonia storage tank, flares, urea storage facilities, workshops and other plant related buildings. The layout appeared to be well-spaced and compact. The plot plant on the bank of the river Kushiara showing temporary jetty, water intake station, water treatment plant and transfer pumps was reviewed and COMPLANT proposed to finalize it by the end of December 2012. COMPLANT in fact did not build the temporary jetty on the river bank.

In order to conduct BED review meetings, independent groups worked in parallel covering processes, utilities and offsites, equipment and machinery, control systems, power generation and distribution, plot plan, civil construction, buildings, storage and material handling, roads/pavements/drainage etc. This arrangement was satisfactory and workable.

After the meeting at Chengdu, the team visited a number of facilities for manufacturing compressors, turbines, pressure vessels and heat exchangers. The team also visited the JienFeng ammonia-urea complex at Chongqing. The ammonia unit is based on KBR's Purifier Process and its process air compressor is GT driven like SFP. The unit has a horizontal ammonia converter and proprietary cold box (Purifier) and its production capacity is $1500 \mathrm{tpd}$ ammonia, which is fed to the urea plant having production capacity of 2700 tpd prilled urea. The urea unit uses Stamicarbon's Urea 2000PlusTM Pool Condenser process. The complex has two single wall ammonia storage tanks with capacity of $5000 \mathrm{t}$ each. The complex had problems with the cold box of ammonia unit and the plant often operated by-passing the cold box. The layout of the complex is compact. CHENGDA had undertaken the engineering of this complex. SFP's operating personnel were trained at this complex while personnel from this complex were brought to SFP for commissioning its plants.

\section{Procurement Activities}

COMPLANT was alone responsible for the procurement of all equipment, machinery, materials, supplies, spare parts, tools, services and package units for the project. It worked independently. It followed a set procedure for its procurement activities. A Request for Quotation (RFQ) would include:

Enquiry letter

Instruction to bidders

General terms and conditions

Inspection instruction

Packaging and transportation instruction 
Technical specification (Material Requirement (MR) prepared with complete description and drawing, quantity, quality and services required)

Proprietary and critical equipment, supplies and units were procured from the approved vendors listed in the contract. In the case of Chinese vendors, a certificate from the end user was required stating five years of successful operation and the certificates were not submitted for some vendors. COMPLANT did not submit the technical specifications for each procurement to SFP and this made it difficult to understand the scope of supply by the vendors including spare parts. Procurement documents such as General Terms and Conditions, Inspection Instruction, and Packaging and Transportation Instruction complied with requirements of the signed contract.

COMPLANT placed a purchase order for the auxiliary boilers with a non-approved vendor, Beijing Boiler Works (BBW) without the approval of SFP. When asked to provide the proven experience of BBW, it could not produce any document to prove its experience of supplying natural gas fired boilers generating steam at the rate of $75 \mathrm{t} / \mathrm{hr}$ at $5 \mathrm{MPaG}$ and 400 C. It became fait accompli for SFP/BCIC who approved BBW as vendor for boilers on December 11, 2013 while the purchase order had been placed on December 12, 2012. The approved list included 12 vendors for boilers. The purchase order with $\mathrm{BBW}$ was placed for two boilers generating $85 \mathrm{t} / \mathrm{hr}$ steam at $5 \mathrm{MPaG}$ and $400 \mathrm{C}$. When the boilers were installed, the nameplates read steam generation rate $75 \mathrm{t} / \mathrm{hr}$. SFP and BCIC swallowed this outrageous exception mysteriously. When brought to the notice of VicePresident of COMPLANT, there was no response.

COMPLANT procured catalysts for Shift Converters (HTS and LTS) from Chinese vendors who were not listed in the approved vendors' list of KBR. SFP's disapproval was ignored by COMPLANT while KBR remained unconcerned.

Inspection at the vendors' shop during the manufacturing stages of equipment and supplies is an important activity for quality assurance; and both the GC (COMPLANT/CHENGDA) and Owner (SFP) were expected to be physically present to witness tests and examination as per QA/QC program. The contract between BCIC and COMPLANT as well as the contracts between VENDORS and COMPLANT clearly stipulated that both COMPLANT and the vendors would inform SFP the schedule of inspection at least three weeks ahead of actual inspection or test date. COMPLANT failed to notify SFP the inspection schedule in time. COMPLANT did not submit the vendor shop inspection dossiers with shipping documents or with the consignments. The situation did not change in spite of reporting to COMPLANT's senior management in Beijing. SFP's appointed Third Party Inspector, TUV could complete inspection on 55 of its assigned jobs out of 213. The situation was difficult with vendors from China; and SFP was frustrated and disappointed.

The total number of consignments shipped to Bangladesh up to January 29, 2016 was 146 and the first consignment consisting of underground cooling water pipes reached Bangladesh in November 2012. Consignments came from Europe, Japan, USA and China. These were delivered to Chittagong and Mongla ports. Not a single consignment or a container of any consignment was miss-shipped or lost. This is an incredible achievement by COMPLANT.

\section{Liquid Ammonia Storage Tank}

At the proposal stage COMPLANT proposed two atmospheric liquid ammonia storage tanks with capacity of $3800 \mathrm{t}$ each, having a total capacity of $7600 \mathrm{t}$. The signed contract stipulated for one 10,000 $\mathrm{t}$ capacity tank. SFP asked for double wall construction while COMPLANT/CHENGDA insisted on single wall type construction.

At the BED meeting, it was agreed that construction type and holding capacity of $10000 \mathrm{t}$ whether in one or two tanks would be settled in Dhaka. This issue was placed before the meeting of the Steering Committee of SFP held on December 12, 2012 and it was agreed to have two ammonia storage tanks each holding $5000 \mathrm{t}$ and of single wall construction following API-620 (latest edition) for design and construction.

CHENGDA proposed to use equivalent Chinese Standards for materials of construction. These two tanks were field fabricated by China National Chemical Engineering No. 7 Construction Company Ltd. The tanks were placed inside a dyke with a partition wall to divide the dyke into two, one for each tank. KBR had no reservation about the construction type whether double wall or single wall.

\section{Installation of Customer Metering Station (CMS)}

The Customer Metering Station (CMS) for regulating the natural gas flow to the users, in this case SFP, was supposed to be built by Petrobangla's - 
designated Gas Distribution Company, Jalalabad Gas Transmission and Distribution Co. Ltd. (JGTDCL) as per permission letter issued to BCIC/SFP. The CMS is used to meter the gas flow to the customer and bill per this meter reading/measurement. It had been Petrobangla's practice for many decades to build/install the CMS by its designated Gas Distribution Company while the entire costs are borne by the customer by placing funds to Petrobangla or its company in advance. The permission letter of Petrobangla stated the same procedure. The ownership of CMS lies with the Gas Company who operates and maintains the station. With the influx of gas based rental power companies, independent power producers and other industrial customers the Gas Companies have of late introduced the concept of 'Building CMS by Customers Themselves' while the Gas Companies are to be paid for their services equal to $10 \%$ of the cost of CMS.

SFP's willingness to accept the responsibility for building its CMS instead of JGTDCL was suicidal as it failed to build CMS on schedule. The contractor for CMS was selected after two failed tenders. SFP signed a contract with the CMS contractor in May 2015 while as per the contract signed between BCIC and COMPLANT the natural gas would have been available before June 15, 2014 (after 26th month from EDC). Actual commissioning of CMS took place on February 25, 2017 almost twenty months behind the contracted completion time.

In order to meet the deadline for availing natural gas to SFP's battery limit, SFP and JGTDCL resorted to building a temporary Regulatory Metering Station (RMS) and it was in operation from May 2015. However, natural gas was made available to SFP in January 2015 for pre-commissioning activities through alternative pipelines from the NGFF system before the construction of the temporary RMS.

COMPLANT used this delay for CMS and temporary RMS as an excuse for extending project completion time.

\section{Mechanical Completion}

As soon as the erection and construction of a section or unit had been completed, COMPLANT requested SFP to participate in mechanical completion. But COMPLANT did not provide SFP with Mechanical Completion Procedure as scheduled in spite of repeated reminders. However, SFP personnel participated in the program but when COMPLANT asked for the mechanical completion certificate, it did not submit the necessary punch list or report of actual findings of the program signed by the participants in the work from SFP and
COMPLANT. This led to a delay in processing COMPLANT's application for mechanical completion certificate. Both COMPLANT and CHENGDA failed to appreciate SFP's intention of undertaking mechanical completion work according to good engineering practice. Instead, they took it as hit-or-miss work.

The problems encountered during start-up and commissioning with Natural Gas (feed) Compressor, Carbon Dioxide Compressor, Methanator FeedEffluent Cooler, $\mathrm{CO} 2$ - Recovery Unit, Urea Granulators, Auxiliary Boilers, and Process Air Compressor etc. were related to mechanical completion as well as changes made during detailed engineering by ignoring Licensor's BED. Moreover, COMPLANT attempted to hasten the completion of the project as its progress had been behind the schedule. This created more problems for the start-up personnel from CHENGDA and Jiangfeng as they were yet to be conversant with the machinery installed. They ignored start-up and operating procedures of vendors including safety matters. When the problems had started to multiply the startup team from CHENGDA became nervous and they changed their strategy to proceed with caution and step by step.

\section{Start-up and Commissioning}

As soon as natural gas had become available to SFP at the rate of 16 MMSCFD through the temporary line from the NGFF system from January 24, 2015 COMPLANT initiated start-up of the units that required natural gas. Full requirement of natural gas became available in May, 2015 from the newly built temporary RMS

As the start-up progressed problems were encountered with auxiliary boilers and these were related to foundation of boilers, undersize coupling for FD Fan and motor, and motor operated valves etc. Problems were faced with steam turbine generators and these were related to controllers, governors and valves.

After the elimination of the problems with boilers and STG, the commissioning of ammonia unit was started. Problems were found with Process Feed Gas Compressor, Methanator Feed-Effluent Cooler and Plate Exchanger in CO2-Recovery Section. Though the first drop of ammonia was produced on August 03, 2015 at $06.15 \mathrm{am}$, the plant could not operate above $70 \%$ of the rated capacity. At the same time when urea melt unit was started, problems were encountered with $\mathrm{CO} 2$-Compressor. These problems were identified by opening the casings and eliminated by the middle of September. The first urea granule 
was dropped on conveyor belt on September 20, 2015 at $07: 30 \mathrm{pm}$. Due to the problems in the ammonia unit with Feed Gas Compressor and Methanator Feed-Effluent Cooler, the plant load of ammonia unit could not be raised above $70 \%$ which meant that the urea melt unit could not operate above $70 \%$ capacity. These defects were eliminated by the respective vendors through modifications by the end of the first week of November 2015. The ammonia unit was then brought on stream on November 08, 2015. The ammonia unit during the period from August 03 to November 07, 2015 produced 7,913 $\mathrm{t}$ ammonia while during the period from September 20 to October 04, 2015 the total granular urea produced was 8,930 $\mathrm{t}$ measured by the Belt Weighing Scale.

\section{Performance Guarantee Test Runs (PGTR)}

The contract stipulated that PGTR would be preceded by successful completion of

a. Steady operation of the whole complex for at least seven days on a safe and continuous basis

b. Demonstration operation of the whole complex for at least 10 days uninterrupted at minimum $90 \%$ load keeping all units running

After successful completion of (a) and (b), the General Contractor would undertake Performance Tests of

a. Ammonia Unit for three days

b. Urea Melt and Granulation Units for three days

c. Overall Complex for ten days

without any interruption; and performance tests of the offsite and utilities would be completed as per design. Table 4 lists these operations and tests.

COMPLANT claimed that the operation since commissioning of Ammonia and Urea Units up to October 04, 2015 would be treated as a steady operation. Unfortunately, due to various problems with plant equipment the complex failed to operate above $70 \%$ capacity and suffered many interruptions. The load of the complex could be raised above $70 \%$ after November 07, 2015 when the defects in Ammonia Unit were eliminated. During the period up to November 07, 2015 the operation of the complex as well as production of granular urea and ammonia were interrupted several times and capacity remained below 70\%. The 10-day Demonstration Operation of the Complex uninterrupted at minimum $90 \%$ capacity that started from November 14, 2015 was interrupted twice for $28 \mathrm{hrs} 34$ mins in total due to problem with CO2 Compressor Turbine (7 hrs 10 mins) and total blackout for the outage two STGS one after another (21 hrs 24 mins). COMPLANT did not consider these two stoppages as interruption. Since the interruptions occurred after seven days of operation (on November 22 and 24), COMPLANT attempted a fresh 3-day Demonstration Run from November 25 but failed to complete it due to interruption on November 27 for 3 hrs 30 mins while capacity achieved was below $90 \%$.

Table 4

List of operations leading to PGTR of the complex

\begin{tabular}{ll}
\hline Operation & Duration \\
\hline 1. Steady Operation of Whole Complex & $\begin{array}{l}7 \text { days at } \\
\text { least }\end{array}$ \\
2. Demonstration Operation of Whole & 10 days at \\
Complex at 90\% Load (minimum) with & least \\
all units running without interruption & \\
3. PGTR of Ammonia Unit & 3 days \\
4. PGTR of Urea Melt and Granulation & 3 days \\
Units & 10 days \\
5. PGTR of the Overall Complex & 3 days \\
6. Performance Tests of Offsites and & 3 days \\
Utilities & 3 days \\
a. Raw Water Supply & 3 days \\
b. Raw Water Treatment & 3 days \\
c. Demineralization & 3 days \\
d. Cooling Water System & 3 days \\
e. Steam Generation and Distribution & 3 days \\
f. Power Generation and Distribution & 3 days \\
g. Instrument and Plant Air System & 3 days \\
h. Nitrogen Generation System & \\
i. Wastewater Treatment System & \\
7. Demonstration of the Design Capacity & \\
a. Natural Gas System & \\
b. Ammonia Storage Tanks & \\
c. Bulk Product Handling and Storage & \\
d. Urea Bagging and Bagged Storage & \\
e. Polyethylene Bag Making plant & 24 hrs. \\
\hline
\end{tabular}

During the Demonstration Operation of the complex COMPLANT/CHENGDA along with Stamicarbon carried out 3-day PGTR for Urea Melt and Urea Granulation Units from November 15, 2015 (9.00 hrs) to November 18 (9.00 hrs.). The 3-day PGTR for Ammonia Unit was carried out from November 19 (9.00 hrs.) to November 22, 2015 (9.00 hrs) by COMPLANT/CHENGDA along with KBR. SFP's personnel were not involved in these 3-day PGTRs. Personnel from Stamicarbon and KBR did not meet SFP personnel nor did they discuss the results of PGTR with them. This was an unexpected and weired behavior by the process licensor as if the COMPLANT and CHENGDA owned SFP. 
COMPLANT/CHENGDA started the 10-day Overall Performance Tests from November 29, 2015 $(00.00 \mathrm{hr})$. The complex suffered four interruptions resulting in the stoppage of urea granule production on November 30 (1 hr 47 mins.), December 02 (30 mins), December 02 (30 mins) and December 03 (3 hrs 30 mins). SFP rejected this 10-day Over-all Performance Tests on the ground of interruptions and wrong reading by Belt Weighing Scale for measuring urea production. It was discovered that though the scale was calibrated, the zero setting altered upward showing more production against actual bagged product by about 5.5 to $6.8 \%$. Actual consumption of ammonia for producing the product urea granules had confirmed this and calculation showed that ammonia consumption was less than the stoichiometric requirement for the urea produced recorded by the Belt Weighing Scale.

SFP's rejection of 10-day overall Performance Tests for production stoppage and erroneous reading by Weighing Belt Scale, stalemate arose between SFP and COMPLANT. COMPLANT asked for the intervention of the Ministry of Industry. At the meeting held on December 14 and 15, 2015 with the Secretary of MoI in the chair, it was agreed that the GC would undertake a 7-day Uninterrupted Operation of the Complex by direct bagging of granular urea at $100 \%$ capacity. If this 7-day uninterrupted operation would be fulfilled SFP would accept the reports on 10-day Demonstration Run, 3day PGTR and completed 10-day Overall Performance Test results, and issue the Final Acceptance Certificate.

Accordingly, COMPLANT completed the "7-day Uninterrupted Production by Direct Bagging of Granular Urea" during the period from January 10 (14:30 hrs) to January 17, 2016 (14: $30 \mathrm{hrs)} \mathrm{by}$ following an agreed procedure. This operation was interrupted for $15 \mathrm{hrs} 33 \mathrm{~min}$ due to failure of SFP to provide laborers for removing urea bags from the conveyor belt coming to the bagged storage area. Many of those engaged in the test run suspected this failure of SFP to be a planned sabotage to help COMPLANT. During this period of $15 \mathrm{hrs} 33 \mathrm{mins}$ granular urea produced was diverted to the bulk storage. This operation showed that average daily production of ammonia $1011.98 \mathrm{t}$ and that for granular urea $1774.85 \mathrm{t}$ while daily average daily production by direct bagging was $1775.29 \mathrm{t}$.

\section{Issue of Provisional Acceptance Certificate}

After examination and evaluation of all the reports related to Demonstration Operation, PGTR for 3 days, Overall Performance Tests for 10 days and 7- day Uninterrupted Operation by direct bagging of urea, SFP decided to accept the reports in spite of limitations and questions. Since some of the works and issues were yet to be settled and supplies to be delivered by COMPLANT, it was decided that the General Contractor would be issued a Provisional Acceptance Certificate with effect from February 29, 2016 though there was no such provision in the Contract. This was done without imposing liquidated damage of any kind

\section{Documentation in SFP}

SFP's own preparation for managing and preserving documents of the project was poor. It failed to build its library for preserving documents submitted by COMPLANT. This was a willful negligence and not ignorance.

On the other hand, COMPLANT had never realized that documentation is the vehicle for transfer of technology for SFP to operate, maintain and make modifications of the project. Documents prepared and submitted by COMPLANT and CHENGDA were often found to be not organized and consistent as these were translation of originals in Chinese. These lacked careful editing and compilation, thereby failing to meet their objectives. Documents from some Chinese vendors prepared in Chinese language were not even translated for SFP.

Documents such as Process Design Package (PDP), specifications and procedures submitted by Process Licensors were well prepared and comprehensive. Similarly, documents by vendors/manufacturers from Europe, USA and Japan were organized and comprehensible, thus meeting the requirements of SFP.

SFP repeatedly requested COMPLANT to improve the quality of documentation and to follow the document samples provided by SFP. The situation did not improve. SFP was apprehensive of such a situation while going through the documentation of technical proposals but it could not foresee that things would be so bad.

Submission of documents by COMPLANT was not as per contractual schedules and repeated reminders had no effect.

Documents submitted by COMPLANT as soft copy were not printed by SFP in many cases and printed copies were not sent to the technical library as routine matter for preservation. The library was set up towards the end of project implementation. 


\section{BCIC's Involvement in SFP}

Since the completion of JFCL in 1992, BCIC had been eager and serious to build one new grass-roots ammonia-urea complex of the size of CUFL/JFCL at a place close to NGFF for its replacement. The problem was finding a funding source. When the funds from China with the Chinese General Contractor, COMPLANT has become available, BCIC looked nervous as it did not have confidence in the competence Chinese GC as well as the equipment and materials from China.

A section of BCIC personnel who were supposed to implement SFP distanced themselves from the project. Many important and responsible people in the decision making process did not believe that SFP would ever produce urea. They openly said that heads would roll in SFP/BCIC for its failure.

Right from the start when COMPLANT had submitted its proposal in September 2010, BCIC failed to appoint key personnel as a core team consisting of Project Director (permanent), Construction Manager, Procurement Manager, Lead Engineers for processes, utilities, civil, mechanical, electrical, instruments and controls, inspection, HSE etc. BCIC and SFP never had a core team consisting of experienced personnel throughout the implementation of the project. SFP thus failed itself and BCIC to get the project grasped technologically.

The twenty-year gap between JFCL and SFP created a big hole in the mindset of BCIC to appreciate and visualize the interlinked aspects of implementing a complex project like SFP as well as technological advances made.

The top management of BCIC and SFP were infected with 'Chair Syndrome' virus and behaved like a mediaeval Sultan who acts as if he rules half the planet. They were not sure what they are up to. They were used to change their decisions continuously without assigning reasons. This was too much for the morale of the SFP personnel on the ground.

SFP's PD was flexible and accommodating in order to get the project completed by pleasing concerned and unconcerned people including the GC. What else could PD do given the context of Bangladesh?

BCIC appointed EIL (Engineers India Ltd) about eighteen months in the project implementation to assist SFP. BCIC had failed to realize that in the aided projects of the World Bank, Asian Development Bank, OECEF (Japan), IMF, CIDA etc., there is a requirement by the financers to engage consultants appointed by them to oversee the project implementation on their behalf. Examples are: AFCL, CUFL, JFCL, and ERL. SFP and BCIC should evaluate the contribution of EIL to the project for justifying its appointment.

\section{Ammonia-Urea Industry of China}

China has a large technological base and capacity for producing ammonia and urea fertilizer. In China, there are 29 large plants with annual production capacity of 300,000 t ammonia each, 52 medium size plants with annual production of $60.000 \mathrm{t}-180,000 \mathrm{t}$ ammonia and 120,000 t - 300,000 t urea each and more than 500 small plants producing annually less than $60,000 \mathrm{t}$ ammonia each. The shares of production of urea by large, medium and small plants are $31.5 \%, 17.9 \%$ and $50.6 \%$ respectively. Raw materials for production of ammonia are coal $(65 \%)$, natural gas (28\%) and heavy oil (7\%).

Besides its indigenous process technologies and equipment, China in the past fifty years has endeavored to license and acquire all process technologies for ammonia using different raw materials and urea production as well as to manufacture plant equipment and machinery by allowing subsidiaries to be established in China by all reputed manufacturers from all over the world.

Through adaptation, absorption and innovation, the ammonia-urea industry has matured into a Chinese form that suits local conditions and needs as well as to be reliable and cost-effective. Therefore, there are no valid grounds to doubt the competence of a successful EPC Contractor and proven equipment and materials from China.

The Chinese people are hospitable and polished. They are serious, sincere and well meaning. Language is not a stumbling block for conducting business with them. They value long term business relationships.

Since they have developed their technological base through innovation, adaptation, absorption, applied research and applications, they are proud of their competence and capability. They are unwilling to accept your unfounded criticism and you better not hurt their pride.

COMPLANT throughout the implementation of SFP took full advantage of the weaknesses of the Bangladeshis' character and integrity by compromising SFP's interest. 


\section{Lessons Learned}

SFP has once again reinforced:

a. Lack of commitment is counterproductive for a project.

b. Inadequate preparation without a core team fails the objectives of the adaptation and transfer of technology in an engineering project.

c. Frequent changes in top management undermine the continuity and philosophy for implementing a complex project like SFP.

d. Documentation shall be prioritized for supporting the future projects.

e. Do not believe in hearsay.

f. Do not be a judge on matters that you do not know or understand little or not at all.

g. Maintain integrity and do not sell your soul.

The author has used information available with him collected over many years and during the implementation of SFP.

\section{Reference}

[1] Quader, A.K.M.A. (2015). Strategy for the Urea Fertilizer Sector in Bangladesh, presented at the Seminar 'Challenges Facing the Fertilizer Sector and Recommended Course of Action' held in Dhaka, Bangladesh. 